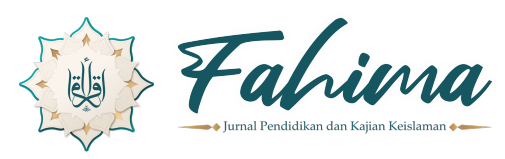

Fahima: Jurnal Pendidikan dan Kajian Keislaman

E-ISSN: 2808-4349 | P-ISSN: 2808-747X | Volume 1 No. 1 Januari 2022

\title{
PENGARUH PEMBELAJARAN JARAK JAUH DI TENGAH PANDEMI COVID-19 DAN KECEMASAN ORANG TUA TERHADAP PERILAKU RELIGIUS SISWA
}

\begin{tabular}{|c|c|c|c|}
\hline \multicolumn{4}{|c|}{ Dyah Surti Murdiningsih $^{*}$, Mulyoto $^{2}$} \\
\hline \multicolumn{4}{|c|}{${ }^{1}$ Program Pascasarjana UNU Surakarta, Indonesia } \\
\hline \multicolumn{4}{|c|}{${ }^{2}$ Universitas Sarjanawiyata Tamansiswa Yogyakarta, Indonesia } \\
\hline \multicolumn{4}{|c|}{ *Surel Penulis Koresponden: dyahsurtimurdiningsih@gmail.com } \\
\hline \multicolumn{4}{|c|}{ Riwayat Artikel: } \\
\hline Dikirim: 4/11/2021 & Ditinjau: 15/11/2021 & Diperbaiki: $2 / 1 / 2022$ & Diterima: $3 / 1 / 2022$ \\
\hline
\end{tabular}

\begin{abstract}
Abstrak
Tujuan penelitian ini adalah: 1) Mengetahui pengarub pembelajaran jarakjauh di tengah pandemi Covid-19 terbadap perilaku religius siswa SMP Mubammadiyah 1 Kartasura tabun pelajaran 2020/2021, 2) Mengetahui pengarub kecemasan orang tua terhadap perilaku religius siswa SMP Mubammadiyah 1 Kartasura tahun pelajaran 2020/2021, 3) Mengetabui pengarub pembelajaran jarak, jauh di tengah pandemi Covid-19 dan kecemasan orang tua terhadap perilaku religius siswa SMP Muhammadiyah 1 Kartasura tabun pelajaran 2020/2021.

Penelitian ini merupakan penelitian kuantitatif. Sampel penelitian ini adalah 72 siswa SMP Muhammadiyah 1 Kartasura tabun pelajaran 2020/2021. Pengujian instrumen menggunakan uji validitas dan reliabilitas. Uji asumsi klasik menggunakan uji normalitas, uji multikolinieritas dan uji heteroskedastisitas. Teknik analisis data menggunakan Regresi Linier Berganda, uji F, uji t dan koefisien determinasi (R2).

Hasil penelitian menunjuk.kan bawa pengaruh pembelajaran jarak jaub di tengah pandemi Covid-19 terhadap perilaku religius siswa SMP Mubammadiyah 1 Kartasura tabun pelajaran 2020/2021 terbukti berpengaruh negatif. Pengarub kecemasan orang tua terhadap perilaku religius siswa SMP Muhammadiyah 1 Kartasura tabun pelajaran 2020/2021 terbukti berpengaruh positif. Pengaruh pembelajaran jarak jaub di tengah pandemi Covid-19 dan kecemasan orang tua terhadap perilaku religius siswa SMP Mubammadiyah 1 Kartasura tabun pelajaran 2020/2021 terbukti berpengaruh.
\end{abstract}

Kata Kunci: pembelajaran jarak jauh, pandemi covid-19, kecemasan, perilaku religius

Abstract
The aims of this study were to 1) determine the effect of distance learning during the Covid-
19 pandemic on the students' religious behavior; 2) determine the effect of parental anxiety on the 
students' religious behavior, 3) Knowing the effect of distance learning during the Covid-19 pandemic and parental anxiety about the students' religious behavior of Mubammadiyah 1 Kartasura Junior High School academic year 2020/2021.

This research is quantitative. The sample of this study was 72 students of Mubammadiyah 1 Kartasura Junior High School academic year 2020/2021. Test the instrument using validity and reliability tests. Classical assumption test using normality test, multicollinearity test, and heteroscedasticity test. The data analysis technique used Multiple Linear Regression, F test, t-test, and coefficient of determination (R2).

The results showed that distance learning during the Covid-19 pandemic on the religious behavior of Muhammadiyah 1 Kartasura Junior High School students academic year 2020/2021 proved to have a negative effect. The effect of parental anxiety on the religious behavior of Muhammadiyah 1 Kartasura Junior High School students academic year 2020/2021 has been proven to impact positively. The impact of distance learning during the Covid-19 pandemic and parental anxiety on the religious behavior of Muhammadiyah 1 Kartasura Junior High School students academic year 2020/2021 has proven to be influential.

Keywords: distance learning, covid-19 pandemic, anxiety, religious behavior

\section{A. PENDAHULUAN}

Mayoritas lembaga pendidikan di Indonesia mengkonversi pembelajaran tatap muka menjadi pembelajaran daring atau Pembelajaran Jarak Jauh (PJJ) dengan keterpaksaan dan ketidaknyamanan pada saat Covid19 mewabah. Salah satu efek transformasi mendadak moda pembelajaran tersebut adalah munculnya berbagai laporan atau pengaduan terkait kesulitan yang dihadapi siswa maupun orang tua dalam mengikuti PJJ (pembelajaran jarak jauh). Sampai akhir April 2020, Komisi Perlindungan Anak Indonesia (KPAI) menerima sedikitnya 246 pengaduan terkait hal tersebut. Hal-hal yang menjadi poin aduan, antara lain, adalah beban tugas dari guru yang berlebih, pembelajaran yang bersifat satu-arah, pemberlakuan jam pembelajaran seperti pembelajaran tatap muka, biaya pendidikan yang tetap kendati sebagian beban pembelajaran berpindah menjadi tanggung jawab keluarga, hingga keterbatasan kuota internet dan perangkat untuk berpartisipasi dalam PJJ. Belum lagi keluhan dari orang tua yang juga harus mengalokasikan waktu lebih banyak untuk mendampingi anak mereka (Musfah, 2020).

Di Indonesia, pembelajaran jarak jauh atau daring ini dimulai pada tanggal 16 Maret 2020, dimana anak mulai belajar dari rumahnya masingmasing tanpa perlu pergi ke sekolah. Konsekuensi dari penutupan Lembaga Pendidikan secara fisik dan mengganti dengan belajar di/dari rumah sebagaimana kebijakan pemerintah adalah adanya perubahan sistem belajar mengajar. Pengelola sekolah, siswa, orang tua, dan tentu saja guru harus bermigrasi ke sistem pembelajaran digital atau online, yang lebih dikenal dengan 
istilah e-learning atau dikenal dengan istilah Pembelajaran Jarak Jauh (PJJ) (Yunitasari \& Hanifah, 2020).

Kelangsungan pendidikan selama pandemi tersebut akan tergantung pada berbagai faktor, seperti tingkat persiapan sekolah, kesiapan orang tua/keluarga, serta kesiapan guru.

Jenjang pendidikan dari Pendidikan Anak Usia Dini (PAUD) Sekolah Dasar/Ibtidaiyah sampai Perguruan Tinggi (Universitas) baik yang berada di bawah Kementerian Pendidikan dan Kebudayaan Republik Indonesia maupun yang berada di bawah Kementerian Agama Republik Indonesia semuanya memperoleh dampak negatif karena peserta didik, pelajar, siswa dan mahasiswa dipaksa belajar dari rumah karena pembelajaran tatap muka ditiadakan untuk mencegah penularan Covid-19. Padahal tidak semua peserta didik, pelajar, siswa dan mahasiswa terbiasa belajar melalui online. Apalagi guru dan dosen masih banyak belum mahir mengajar dengan menggunakan teknologi internet atau media sosial terutama di berbagai daerah.

Dampak negatif, pembelajaran daring mempuyai banyak manfaat, yang pertama: dapat membangun komunikasi dan diskusi yang sangat efisien antara guru dengan murid, kedua siswa saling berinteraksi dan berdiskusi antara siswa yang satu dengan yang lainnya tanpa melalui guru, ketiga dapat memudahkan interaksi antara siswa guru, dengan orang tua, keempat sarana yang tepat untuk ujian maupun kuis, kelima guru dapat dengan mudah memberikan materi kepada siswa berupa gambar dan video selain itu murid juga dapat mengunduh bahan ajar tersebut, keenam dapat memudahkan guru membuat soal di mana saja dan kapan saja (Yunitasari \& Hanifah, 2020).

Situasi tatanan hidup akibat pandemi bukanlah hal yang mudah bagi anak maupun orang tua, dibutuhkan suatu adaptasi di lingkungannya. Dikutip dari The Union Journal, dampak psikologis yang dapat terjadi bagi pada anak di masa ini di antaranya perilaku regresif, perubahan nafsu makan dan mengalami gangguan tidur. Dampak lain yaitu anak sulit berkonsentrasi, ada perubahan suasana hati seperti mudah marah dan menangis, keluhan somatik, anak lebih banyak main gawai, lebih banyak menonton TV dan anak cenderung mengalami kondisi emosi yang tidak stabil. Orang tua banyak yang mengeluhkan selama anak belajar di rumah dikarenakan kurang efektifnya pembalajaran dengan sistem ini, baik dari segi penyampaian materi, waktu dan pemberian tugas individu yang terkadang memberatkan peserta didik. Tidak sedikit dari orang tua merasa lebih khawatir jika tidak mampu melaksanakan pemantauan pembelajaran anak, pemenuhan fasilitas dan akan berdampak pada kemampuan akademik anak (Musfah, 2020).

Kemudian hasil studinya Resti dan Suyadi juga menyampaikan bahwa dampak dari kuliah daring terhadap perilaku religius mahasiswa kurang baik 
seperti: lupa jadwal, mata lelah, pemahaman materi kurang, masalah dengan koneksi internet, sholat lima waktu sering ditinggalkan, jarang membaca AlQur'an dan tidak melaksanakan Sholat Jum'at (Hanisa \& Suyadi, 2020). Penelitian ini mengggunakan pendekatan kualitatif. Dasar penelitian ini diperoleh berasal dari literatur jurnal ataupun buku di bidang Covid-19, pendidikan Islam, catatan lapangan, dan ucapan responden.

Brown dkk dalam risetnya menambahkan orang tua mengalami stressor kumulatif akibat Covid-19. Mengenai stressor spesifik, sekitar 21\%$47 \%$ orang tua melaporkan bahwa anak mereka masing-masing mengalami perubahan pada kesehatan dan pembelajaran mereka akibat Covid-19. Stressor yang paling umum terjadi pada orang tua termasuk pada perubahan suasana hati dan tingkat stres secara umum. Demikian pula, mayoritas orang tua dilaporkan mengalami gejala kecemasan dan depresi serta kurang tidur (Brown dkk., 2020). Pembelajaran jarak jauh mengganggu kehidupan orang tua dan menimbulkan rasa cemas. Rasa cemas yang dirasakan lebih besar pada orang tua siswa SD, SMP dan SMA dibandingkan yang sudah mahasiswa (Tirajoh dkk., 2021).

\section{B. METODE PENELITIAN}

Penelitian ini merupakan penelitian kuantitatif. Rancangan penelitian yang digunakan adalah analitic regression (pengaruh antara variabel independen dengan dependen) dengan menggunakan pendekatan cross sectional (satu waktu), yaitu untuk mengukur pengaruh pembelajaran jarak jauh di tengah pandemi Covid-19 dan kecemasan orang tua terhadap perilaku religius siswa SMP Muhammadiyah 1 Kartasura Tahun Pelajaran 2020/2021.

Penelitian ini dilaksanakan di SMP Muhammadiyah 1 Kartasura yang beralamat di Jl. A. Yani No. 160, Dusun III, Kartasura, Kecamatan Kartasura, Kabupaten Sukoharjo, Jawa Tengah.

Populasi dalam penelitian ini adalah seluruh siswa SMP Muhammadiyah 1 Kartasura tahun pelajaran 2020/2021 yang berjumlah 358 siswa dari tiga kelas. Teknik pengambilan sampel dengan menggunakan proportionate stratified random sampling dimana populasi mempunyai anggota/unsur yang tidak homogen dan berstrata secara proporsional (Sugiyono, 2016). Maka didapat sampel dalam penelitian ini sebanyak 72 responden.

Penelitian ini, metode angket menjadi metode pokok dalam mengumpulkan data. Angket disebarkan pada responden untuk mengambil data tentang pembelajaran jarak jauh di tengah pandemi Covid-19, kecemasan orang tua dan perilaku religius siswa. Penelitian ini, peneliti menggunakan 
instrumen pokok berupa skala Likert untuk mengumpulkan data terkait pembelajaran jarak jauh, kecemasan orang tua dan perilaku religius siswa.

Teknik analisis data meliputi uji instrumen (uji validitas dan reliabilitas), uji asumsi klasik (uji normalitas, multikolinieritas dan heteroskedastisitas) dan uji regresi (uji F, uji t dan $\mathrm{R}^{2}$ ).

\section{HASIL DAN PEMBAHASAN}

\section{Pengaruh Pembelajaran Jarak Jauh di Tengah Pandemi Covid- 19 dan Kecemasan Orang Tua Terhadap Perilaku Religius Siswa SMP Muhammadiyah 1 Kartasura Tahun Pelajaran 2020/2021}

Hasil pengujian dalam penelitian ini terbukti bahwa pembelajaran jarak jauh di tengah pandemi Covid-19 dan kecemasan orang tua berpengaruh signifikan terhadap perilaku religius siswa SMP Muhammadiyah 1 Kartasura tahun pelajaran 2020/2021 dengan perolehan nilai $F_{\text {hitung }}>F_{\text {tabel }}(19,806>3,15)$ dan nilai probabilitas sebesar $0,000<$ 0,05 .

Hasil penelitian diketahui pembelajaran jarak jauh di tengah pandemi Covid-19 dan kecemasan orang tua berpengaruh signifikan terhadap perilaku religius siswa SMP Muhammadiyah 1 Kartasura tahun pelajaran 2020/2021, hal ini mengindikasikan bahwa pembelajaran jarak jauh di tengah pandemi Covid-19 dan kecemasan orang tua siswa secara bersamasama berpengaruh signifikan terhadap perilaku religius siswa SMP Muhammadiyah 1 Kartasura tahun pelajaran 2020/2021. Dampak dari pandemi mengharuskan pembelajaran dilakukan secara daring yang kemudian memberikan efek terhadap perilaku religius siswa kurang baik.

Pembelajaran daring atau Pembelajaran Jarak Jauh (PJJ) dengan keterpaksaan dan ketidaknyamanan pada saat Covid-19 mewabah memunculkan berbagai permasalahan seperti kesulitan yang dihadapi siswa maupun orang tua dalam mengikuti PJJ, beban tugas dari guru yang berlebih, pembelajaran yang bersifat satu-arah, pemberlakuan jam pembelajaran seperti pembelajaran tatap muka, biaya pendidikan yang tetap kendati sebagian beban pembelajaran berpindah menjadi tanggung jawab keluarga, hingga keterbatasan kuota internet dan perangkat untuk berpartisipasi dalam PJJ.

Situasi tatanan hidup akibat pandemi bukanlah hal yang mudah bagi anak maupun orang tua, dibutuhkan suatu adaptasi di lingkungannya Orang tua banyak yang mengeluhkan selama anak belajar di rumah 
dikarenakan kurang efektifnya pembalajaran dengan sistem ini, baik dari segi penyampaian materi, waktu dan pemberian tugas individu yang terkadang memberatkan peserta didik. Tidak sedikit dari orang tua merasa lebih khawatir jika tidak mampu melaksanakan pemantauan pembelajaran anak, pemenuhan fasilitas dan akan berdampak pada kemampuan akademik anak.

Kemudian hasil studinya Resti dan Suyadi juga menyampaikan bahwa dampak dari kuliah daring terhadap perilaku religius mahasiswa kurang baik seperti: lupa jadwal, mata lelah, pemahaman materi kurang, masalah dengan koneksi internet, sholat lima waktu sering ditinggalkan, jarang membaca Al-Qur'an dan tidak melaksanakan Sholat Jum'at (Hanisa \& Suyadi, 2020).

Dikutip dari The Union Joumal, dampak psikologis yang dapat terjadi bagi pada anak di masa pandemi Covid-19 di antaranya perilaku regresif, perubahan nafsu makan dan mengalami gangguan tidur. Dampak lain yaitu anak sulit berkonsentrasi, ada perubahan suasana hati seperti mudah marah dan menangis, keluhan somatik dan membutuhkan kasih sayang serta perlindungan dari orang tua (Musfah, 2020).

Pembelajaran jarak jauh membuat orang tua berperan sebagai guru, dengan mengawasi dan membimbing saat pembelajaran berlangsung. Berikut merupakan masalah-masalah yang muncul selama penerapan pembelajaran jarak jauh baik dari orang tua maupun siswa, di antaranya:

a. Orang tua dan anak merasakan tekanan dalam pembelajaran.

b. Masalah hubungan anak dengan orang tua.

c. Anak tidak fokus dalam belajar.

d. Anak tidak suka dimonitor.

e. Lamanya anak menghadap layar perangkat elektronik.

f. Anak memiliki masalah emosional dan perilaku.

g. Anak mengalami kebosanan dengan aktivitas sehari-hari (Tirajoh dkk., 2021).

Kemudian peran orang tua dalam pembelajaran jarak jauh di tengah pandemi Covid-19 yaitu:

a. Membuat rencana target belajar anak

Situasi belajar di rumah memang kurang ideal seperti saat belajar di sekolah. Untuk itu orang tua perlu membuat adaptasi dan target belajar 
yang realistis sesuai dengan kondisi rumah. Misalnya gangguan seperti adanya saudara yang dapat menganggu kegiatan belajar, sarana dan prasarana belajar daring, serta menyesuaikan dengan jadwal Work. From Home orang tua.

b. Menjalankan kebiasaan yang sama dan ajarkan tanggung jawab

Walaupun hanya di rumah, upayakan anak menjalankan rutinitas harian yang sama ketika belajar di sekolah. Seperti bangun pagi, melakukan kegiatan belajar mengajar daring atau luring, baru setelahnya anak dapat bermain. Hal ini perlu dilakukan agar anak lebih aman, nyaman, dan tidak cemas terhadap perubahan situasi belajar yang ada.

Orang tua juga perlu mengajarkan tanggung jawab kepada anak terhadap tugas sekolahnya selama di rumah. Hal ini agar anak tidak melewatkan waktu belajar untuk melakukan hal yang disukainya terutama bermain. Dengan begitu anak tetap mendapatkan materi pembelajaran secara teratur dan bermain secara seimbang layaknya masa sekolah biasa.

c. Sabar

Selama belajar dari rumah, orang tua akan menjadi tutor anak menggantikan guru. Untuk itu perlu kesabaran dalam membimbing belajar anak. Selain itu, berikanlah pengajaran dengan kasih sayang. Tujuannya agar anak merasa nyaman dan aman dengan situasi belajar di rumah terutama pada masa pandemi.

d. Manfaatkan aplikasi

Perkembangan teknologi masa kini dapat membuat anda menggunakan berbagai aplikasi untuk membantu metode belajar anak. Apalagi anak-nak kini lebih menyukai pembelajaran yang memiliki animasi visual dan auditori yang menyenangkan. Sehingga orang tua tidak melulu memberikan materi pembelajaran secara konvensional.

e. Mempelajari kekuatan dan kelemahan anak

Mengetahui kekuatan dan kelemahan anak untuk belajar sangat penting agar materi pembelajaran mudah diserap olehnya. Orang tua perlu kreatif dalam menggunakan media atau untuk proses belajar di rumah. Misalnya memanfaatkan video tutorial online atau modul berbasis tulisan dan gambar (Burhanudin, 2021).

Guru merupakan faktor utama sebagai pendidik dalam keseluruhan program pendidikan karakter religius di SMP Muhammadiyah 1 Kartasura ini. Hasil dari penerapan pendidikan karakter religius ini dapat dilihat dari 
interaksi antara guru dan karyawan dengan peserta didik, dapat pula dari wali kelas dengan wali murid. Peran guru dalam pelaksaan program ini sebagai fasilitator, motivator, dan inspirator bagi peserta didik dalam menjalankan semua program pendidikan karakter religius ini.

Sholat dhuha merupakan ibadah yang harus dilakukan oleh semua pihak sekolah baik peserta didik, guru, maupun karyawan. Sholat dhuha dilakukan pada pukul 07:00 WIB secara berjamaah. Pelaksanaan sholat dhuha di SMP Muhammadiyah 1 Kartasura bertujuan untuk membiasakan peserta didik melaksanakan sholat sunnah sebelum mengikuti kegiatan belajar mengajar. Hal ini dilakukan sebagai upaya menumbuhkan karakter peserta didik supaya memiliki karakter religius. Karakter religius dapat terbentuk melalui kegiatan secara langsung. Artinya pesrta didik melakukan hal-hal yang berkaitan dengan karakter religisu tersebut. Salah satunya melalui sholat dhuha berjamaah.

Kegiatan sholat dhuha tersebut dapat terlaksana atas kerjasama peserta didik dan guru. Peserta didik dilibatkan dalam proses persiapan seperti menggelar tikar, kemudian menggulung tikar yang telah selesai digunakan untuk sholat dhuha. Hal ini dilakukan supaya peserta didik memiliki karakter tanggung jawab, gotong royong dan sebagainya.

Upaya penanaman pendidikan karakter religius yang dilakukan SMP Muhammadiyah 1 Kartasura juga dilakukan dengan memberikan wawasan kegamaan terhadap peserta didik. Wawasan keagamaan sebagai upaya pembentukan karakter religius di SMP Muhammadiyah 1 Surakarta dilakukan melalui pembacaan hadist. Pembacaan hadist dilakukan setelah peserta didik dan guru melaksanakan sholat dhuha.

Pembacaan hadist di SMP Muhammadiyah 1 Kartasura dilakukan oleh salah satu guru secara bergantian. Melalui pembacaan hadist tersebut diharapkan peserta didik memiliki wawasan keagamaan, dan selajutnya dapat diinternalisasikan dala kehidupan sehari-hari baik dilingkungan sekolah, maupun masyarakat.

Upaya pembentukan karakter religius yang dilakukan SMP Muhammadiyah 1 Kartasura selanjutnya ialah dengan melaksanakan pembacaan ayat suci Al-Qur'an. Pembacaan Al-Qur'an yang diprogramkan SMP Muhammadiyah 1 Kartasura ialah Juz ke-30. Pembacaan dilakukan dengan cara Muroja'ah. Adapun dalam pelaksanaanya surat yang dibaca dalam juz ke-30 sebanyak 2 sampai dengan 3 surah. Selanjutnya salah satu peserta didik memimpin muraja'ah secara bergantian. Artinya setiap peserta didik sesuai dengan jadwal memimpin muraja'ah. Hal tersebut dilakukan supaya peserta didik terbiasa membaca Al-Qur'an melalui 
membaca Al-Qur'an dan memahami makna ayat yang telah dibaca, peserta didik diharapkan dapat menginternalisasikan ajaran agama yang ada. Selain menumbuhkan karakter religius, dengan menjadikan setiap peserta didik memimpin muraja'ah diharapkan peserta didik memiliki rasa percaya diri.

Selain muraja'ah salah satu program yang dimiliki SMP Muhammadiyah 1 Kartasura dalam upaya mewujudkan generasi yang berkarakter adalah adanya program Baca Tulis Al-Qur'an (BTA). Program BTA ini dilakukan dengan tujuan supaya peserta didik dapat membaca AlQur'an. Program BTA di SMP Muhammaditah 1 Kartasura dilakukan diluar kegiatan belajar mengajar, artinya program tersebut tidak masuk dalam mata pelajaran. Program BTA ini dilakukan oleh guru secara langsung. Artinya guru yang memberikan materi dan melakukan pembinaan secara langsung terhadap peserta didik. Setiap satu guru mengajar dan membina 4-5 siswa. Program BTA ini sementara dilakukan hanya untuk kelas IX.

Impementasi pendidikan karakter religius selanjutnya ialah dengan melakukan doa sebelum kegiatan belajar mengajar dilaksanakan. Berdoa sebelum belajar merupakan ajaran agama, salah satu cermin karakter religius adalah menjalankan ajaran agama dan kepercayaan. Hal ini dilakukan supaya peserta didik terbiasa dalam mengerjakan sesuatu pekerjaan diawali dengan berdoa. Adapaun doa yang dibaca secara bersama-sama dengan dipimpin oleh bapak atau ibu guru. Doa yang dibaca ialah doa memohon supaya diberikan tambahan ilmu dan kepahaman terhadap ilmu yang akan dipelajari. pembacaan doa biasanya dimulai ketika pembelajan jam pertama.

Upaya penanaman karakter religius yang selanjutnya di SMP Muhammdiyah 1 Kartasura adalah dengan melakukan doa setelah belajar. Setiap kegiatan belajar mengajar selesai, diakhiri dengan berdoa bersamasama. Pembelajaran di SMP Muhammadiyah 1 Kartasura dimulai pukul 07:00 dan diakhiri pukul 15:00 WIB. Setelah pembelajaran selesai peserta didik dan guru melaksanakan shalat asar berjamaah. Sebelum pulang peserta didik dan guru berdoa, adapaun doa yang dibaca adalah doa setelah belajar. Pembacaan doa dengan dipimpin oleh salah satu guru.

Pembinaan karakter hormat kepada guru di SMP Muhammadiyah 1 Kartasura dilakukan melalui kegiatan bersalaman di gerbang sekolah waktu pagi hari. Setiap pagi hari ada beberapa petugas yakni guru yang berjaga di gerbang untuk menyambut kehadiran peserta didik yang akan menuntut ilmu. Peserta didik memberikan salam dan berjabat tangan kepada guru yang bertugas di pintu gerbang sekolah. Petugas yakni guru yang berjaga di 
pintu gerbang setiapa harinya adalah guru yang berbeda. Hal ini dilakukan untuk lebih mengakarbakan antara peserta didik dengan bapak atau ibu guru. Sikap hormat terhadap guru merupakan salah satu cermin dari nilai karakter religius. Mengucakpakn salam dan berjabat tangan merupakan perintah agma khususnya dalam ajaran agama Islam.

Salam pada hakikatnya adalah doa. Peserta didik memberikan salam artinya mendoakan keselamatan, kebaikan kepada bapak dan ibu guru. Sedangkan bapak dan ibu guru yang menjawab salam pada hakikatnya memberikan doa kepada peserta didik yakni doa keselamatan dan kebaikan. Berjabat tangan dalam islam sngat dianjurkan. Setiap bertemu dengan seseorang diperintahkan untuk saling berjabat tangan. Berjabat tangan dapat melunturkan dosa-dosa kecil akan berguguran. Namun berjabat tangan dilakukan dengan orang yang mahromnya seperti perempuan dengan perempuan dan laki-laki dengan laki-laki.

Penanaman karakter religius yang selanjutnya dilakukan di SMP Muhammadiyah 1 Kartasura adalah dengan melaksanakan sholat Dhuhur dan Ashar secara berjamaah. Sholat dhuhur dan asar merupakan ibadah dalam Islam yang harus dikerjakan. Apabila seseorang yang beragama islam tidak menlaksanakan Sholat maka ia akan mendapat dosa. Melalui kegiatan sholat berjamaah diharapkan peserta didik memiliki keimanan yang baik cinta kepada Tuhan yang Maha Esa. Melalui kegiatan sholat diharapkan peserta didik tidak melakukan kegiatan keji dan mungkar serta tidak melakukan perbuatan yang melangar norma.

\section{Pengaruh Pembelajaran Jarak Jauh di Tengah Pandemi Covid- 19 Terhadap Perilaku Religius Siswa SMP Muhammadiyah 1 Kartasura Tahun Pelajaran 2020/2021}

Hipotesis pertama yang diajukan dalam penelitian ini terbukti bahwa pembelajaran jarak jauh di tengah pandemi Covid-19 berpengaruh signifikan positif terhadap perilaku religius siswa SMP Muhammadiyah 1 Kartasura tahun pelajaran 2020/2021 dengan perolehan nilai $t_{\text {hitung }}>t_{\text {tabel }}$ $(4,610>2,008)$ dan nilai probabilitas $<0,05$.

Hasil penelitian pada hipotesis pertama diketahui pembelajaran jarak jauh di tengah pandemi Covid-19 berpengaruh signifikan negatif terhadap perilaku religius siswa SMP Muhammadiyah 1 Kartasura tahun pelajaran 2020/2021, hal ini mengindikasikan bahwa pembelajaran jarak jauh di tengah pandemi Covid-19 dapat menurunkan secara signifikan perilaku religius siswa SMP Muhammadiyah 1 Kartasura tahun pelajaran 
2020/2021.

Seluruh jenjang pendidikan dari Pendidikan Anak Usia Dini (PAUD) Sekolah Dasar/Ibtidaiyah sampai Perguruan Tinggi (Universitas) baik yang berada di bawah Kementerian Pendidikan dan Kebudayaan Republik Indonesia maupun yang berada di bawah Kementerian Agama Republik Indonesia semuanya memperoleh dampak negatif karena peserta didik, pelajar, siswa dan mahasiswa dipaksa belajar dari rumah karena pembelajaran tatap muka ditiadakan untuk mencegah penularan Covid-19. Kelangsungan pendidikan selama pandemi tersebut akan tergantung pada berbagai faktor, seperti tingkat persiapan sekolah, kesiapan orang tua/keluarga, serta kesiapan guru.

Pembelajaran jarak jauh atau bisa disebut juga pembelajaran daring merupakan pembelajaran yang menggunakan jaringan internet dengan aksesibilitas, konektivitas, fleksibilitas dan kemampuan untuk memunculkan berbagai jenis interaksi pembelajaran (Fikri dkk., 2021). Hasil penelitiannya Resti dan Suyadi menyimpulkan bahwa dampak dari kuliah daring terhadap perilaku religius mahasiswa kurang baik seperti: lupa jadwal, mata lelah, pemahaman materi kurang, masalah dengan koneksi internet, sholat lima waktu sering ditinggalkan, jarang membaca Al-Qur'an dan tidak melaksanakan Sholat Jum'at (Hanisa \& Suyadi, 2020).

Adanya pandemi Covid-19 ini menjadi suatu pelajaran dan hikmah yang bisa didapat yaitu manusia sebagai khalifah di bumi ini kedepannya harus memiliki rasa tanggung jawab yang lebih besar untuk mendukung program pembangunan yang berasaskan pada kearifan lokal, menjaga keseimbangan lingkungan, berusaha dan mencoba memahami hukum alam. Tentu tidak dapat dipungkiri dampak yang ditimbulkan oleh pandemi Covid-19 begitu besar pada manusia. Akan tetapi alam yang sekian tahun lalu telah terluka akibat ulah manusia, saat ini Allah SWT telah memberikan waktu agar alam dapat beristirahat untuk menyembuhkan dirinya sedikit demi sedikit, agar luka ini tidak semakin merugikan kehidupan manusia. Seyogyanya manusia dan alam dapat saling berdampingan saling menjaga, melengkapi untuk kelangsungan bumi kedepan yang lebih indah.

\section{Pengaruh Kecemasan Orang Tua Terhadap Perilaku Religius Siswa SMP Muhammadiyah 1 Kartasura Tahun Pelajaran $2020 / 2021$}

Hipotesis kedua yang diajukan dalam penelitian ini terbukti bahwa kecemasan orang tua berpengaruh signifikan positif terhadap perilaku religius siswa SMP Muhammadiyah 1 Kartasura tahun pelajaran 2020/2021 
dengan perolehan nilai $t_{\text {hitung }}>\mathrm{t}_{\text {tabel }}(2,911>2,008)$ dan nilai probabilitas $<$ 0,05 .

Hasil penelitian pada hipotesis kedua diketahui kecemasan orang tua berpengaruh signifikan positif terhadap perilaku religius siswa SMP Muhammadiyah 1 Kartasura tahun pelajaran 2020/2021, hal ini mengindikasikan bahwa kecemasan orang tua siswa dapat meningkatkan secara signifikan perilaku religius siswa SMP Muhammadiyah 1 Kartasura tahun pelajaran 2020/2021.

Kecemasan merupakan perasaan yang paling umum dialami oleh seseorang termasuk orang tua. Kecemasan digambarkan sebagai respon dari dalam maupun dari luar diri seseorang saat dihadapkan oleh suatu kejadian. Kecemasan diakibatkan oleh kepedulian yang berlebihan akan suatu masalah yang sedang dihadapi (nyata) ataupun yang dibayangkan mungkin terjadi (Miharja \& Fitriyanti, 2020). Kecemasan orang tua diakibatkan oleh kepedulian yang berlebihan akan suatu masalah yang sedang dihadapi (nyata) ataupun yang dibayangkan mungkin terjadi. Terlebih pada saat pembelajaran jarak jauh di Tengah Covid-19.

Kecemasan orang tua dalam pembelajaran daring anak selama pandemi Covid-19 diantaranya (Tirajoh dkk., 2021):

a. Mengkhawatirkan kesehatan anak. Dalam masa pandemi, anak-anak menjadi kurang aktif karena tinggal di rumah saja. Perasaan cepat bosan, lebih sering menonton tv dan bermain perangkat elektronik yang berdampak pada kesehatan semakin memburuk tanpa melakukan aktivitas di luar rumah.

b. Mengkhawatirkan adanya perubahan emosional dan perilaku anak. Adanya kondisi yang sulit ini menjadi rentan bagi kondisi psikologis anak, perubahan pola perilaku seperti mudah marah, pola makan dan tidur yang berlebihan atau kurang dan lain sebagainya.

c. Mengkhawatirkan adanya perubahan pembelajaran. Orang tua lebih khawatir jika tidak mampu membimbing anaknya dan akan berdampak pada kemampuan akademik.

d. Cemas terkait keadaan ekonomi yang sangat berbeda dari sebelumnya. kekhawatiran dari tingkat kesiapan orang tua karena pandemi sangat mendadak dan tidak terduga, orang tua tidak siap untuk perubahan ini. Mereka mengalami kesulitan menyeimbangkan tanggung jawab pekerjaan, rumah, dan pengawasan mereka. Pandemi ini juga membuat orang tua berpikir bagaimana cara untuk mencukupi kebutuhan sehari-hari dengan mempertahankan pekerjaan yang dia miliki ataupun mencari pekerjaan sampingan. 
Orang tua banyak yang mengeluhkan selama anak belajar di rumah dikarenakan kurang efektifnya pembalajaran dengan sistem ini, baik dari segi penyampaian materi, waktu dan pemberian tugas individu yang terkadang memberatkan peserta didik. Tidak sedikit dari orang tua merasa lebih khawatir jika tidak mampu melaksanakan pemantauan pembelajaran anak, pemenuhan fasilitas dan akan berdampak pada kemampuan akademik anak (Musfah, 2020).

Hasil riset ditemukan bahwa orang tua mengalami stressor kumulatif akibat Covid-19. Stressor yang paling umum terjadi pada orang tua termasuk pada perubahan suasana hati dan tingkat stres secara umum. Demikian pula, mayoritas orang tua dilaporkan mengalami gejala kecemasan dan depresi serta kurang tidur (Brown dkk., 2020).

\section{KESIMPULAN}

Berdasarkan hasil analisis data dan pembahasan pada bab sebelumnya, maka diperoleh kesimpulan sebagai berikut:

1. Pengaruh pembelajaran jarak jauh di tengah pandemi Covid-19 terhadap perilaku religius siswa SMP Muhammadiyah 1 Kartasura tahun pelajaran 2020/2021, terbukti berpengaruh secara signifikan negatif, artinya semakin tinggi pembelajaran jarak jauh di tengah pandemi Covid-19 maka akan semakin kurang baik pula perilaku religius siswa.

2. Pengaruh kecemasan orang tua terhadap perilaku religius siswa SMP Muhammadiyah 1 Kartasura tahun pelajaran 2020/2021, terbukti berpengaruh secara signifikan positif, artinya semakin tinggi kecemasan orang tua siswa maka akan semakin baik pula perilaku religius siswa.

3. Pengaruh pembelajaran jarak jauh di tengah pandemi Covid-19 dan kecemasan orang tua terhadap perilaku religius siswa SMP Muhammadiyah 1 Kartasura tahun pelajaran 2020/2021, terbukti berpengaruh signifikan, artinya pembelajaran jarak jauh di tengah pandemi Covid-19 semakin tinggi dapat berdampak kurang baik terhadap perilaku religius siswa, dan semakin tinggi kekhawatiran orang tua maka akan semakin baik pula perilaku religius siswa.

Hasil penelitian menunjukkan bahwa pembelajaran jarak jauh memberikan pengaruh yang lebih besar terhadap perilaku religius siswa. Karena semakin lamanya kegiatan belajar mengajar dilakukan secara daring yang diiringi oleh pembatasan sosial di tengah pandemi belum pasti kapan berakhirnya, akan berdampak buruk dalam perilaku religius siswa. 


\section{E. REFERENSI}

Brown, S. M., Doom, J. R., Lechuga-Peña, S., Watamura, S. E., \& Koppels, T. (2020). Stress and Parenting During the Global COVID-19 Pandemic. Child Abuse \& Neglect, 110, 104699. https://doi.org/10.1016/j.chiabu.2020.104699

Burhanudin. (2021). Inovasi Guru dan Orang Tua dalam Pembelajaran Daring di Sekolah | Jurnal Pendidikan Guru.

https://jurnal.literasikitaindonesia.com/index.php/jurpendigu/articl e/view/188

Fikri, M., Faizah, N., Elian, S. A., Rahmani, R., Ananda, M. Z., \& Suryanda, A. (2021). Kendala dalam Pembelajaran Jarak Jauh di Masa Pandemi Covid-19: Sebuah Kajian Kritis. Journal Education and Development, 9(1), 145-145. https://doi.org/10.37081/ed.v9i1.2290

Hanisa, R. S., \& Suyadi. (2020). Dampak Pembelajaran Daring terhadap Perilaku-perilaku Religius di Tengah Situasi Social Distancing Akibat Pandemi Covid-19. Al Ulya: Jurnal Pendidikan Islam, 5(2), 226-238. https://doi.org/10.36840/ulya.v5i2.287

Miharja, E., \& Fitriyanti, D. (2020). Gambaran Tingkat Kecemasan Orangtua Terhadap Dampak Negatif Gadget pada Anak Usia 6-12 Tahun di Kelurahan Harapan Baru Samarinda. Jurnal Kesehatan Pasak Bumi Kalimantan, 2(2), 103-110. https://doi.org/10.30872/j.kes.pasmi.kal.v2i2.3509

Musfah, J. (2020). Pembelajaran Jarak Jaub Era Covid-19. Litbangdiklat Press.

Sugiyono. (2016). Metode Penelitian Kombinasi (Mixed Methods). CV. Alfabeta.

Tirajoh, C. V., Munayang, H., \& Kairupan, B. H. R. (2021). Dampak Pembelajaran Jarak Jauh Terhadap Kecemasan Orang Tua Murid di Masa Pandemi Covid-19. Jurnal Biomedik: JBM, 13(1), 49-57. https://doi.org/10.35790/jbm.13.1.2021.31715

Yunitasari, R., \& Hanifah, U. (2020). Pengaruh Pembelajaran Daring terhadap Minat Belajar Siswa pada Masa COVID 19. Edukatif: Jurnal Ilmu Pendidikan, 2(3), 232-243. https://doi.org/10.31004/edukatif.v2i3.142 